\section{DISORDERED SYSTEMS}

\section{Spectral Properties of Disordered Chains and Lattices}

By J. Hori. (International Series of Monographs in Natural Philosophy, Vol. 16.) Pp. xi +229. (Pergamon: Oxford, London and New York, January 1969.) 75s; $\$ 10$.

THIs monograph provides a detailed account of the phase theory which has been developed recently, largely by the author, to analyse the properties of disordered lattices. Most of this work has only appeared in research journals over the past four or five years, so that the material of this book is very close to research frontiers. In spite of this, the presentation is such that little specialized knowledge is required and the book would be readily comprehensible to a graduate student about to embark on research in this field.

To the English reader the presentation may sometimes read a little strangely, but this detracts very little from the generally good layout of material accompanied continuously by examples, worked out in detail, usually for simple one-dimensional systems.

The book starts by introducing the basic concepts of phase theory and transfer matrices applied to several lattices with a regular structure. This is followed by a section dealing with older methods of looking at disordered systems, for example, the Green function method, and the connexion is drawn between Dyson's early work and this phase theoretic method. Details are also given of the numerical methods which have been used to investigate the spectrum of disordered systems. Having shown that phase theory provides a simpler description of impurity modes than a Green function theory, the author then goes on to look at peak structures, localization of modes and gap structures for several one-dimensional disordered systems.

The final section of the book goes on to a study of multidimensional systems. Here the complexity restricts the development, but it is shown that the spectral peak structure may be explained in the same general way as in the one-dimensional case. A review of existing approximate methods is given in the last chapter for comparison with the exact phase theoretic results.

The real value of this monograph is that it presents in one slim volume a complete review with applications of the phase theoretic treatment of disordered systems. Most of this theory has been developed in Japan and is not widely known to workers in Britain, who have mainly followed the Green function methods. P. G. DAwBer

\section{University News}

Dr Alvin F. Poussaint, Tufts University Medical School, has been appointed associate professor of psychiatry in the faculty of medicine at Harvard University and to the department of psychiatry at the Massachusetts General Hospital.

Professor G. P. Wibberley, Wye College, has been appointed to the Ernest Cook chair of countryside planning tenable at University Gollege and Wye College, University of London.

The title of professor of pure mathematics has been conferred on Dr P. J. Higgins in respect of his post at King's College, University of London.

The title of professor of physiology in the University of London has been conferred on Professor A. F. Huxley, Jodrell professor of physiology at University College, who will become Royal Society professor at the college. The title of professor of paediatrics has been conferred on Dr T. E. Oppe in respect of his post at St Mary's Hospital Medical School, University of London.
The title of professor of geology has been conferred on Dr J. E. Prentice, King's Gollege, University of London. The title of professor of cellular biology and histology has been conferred on Dr C. L. Foster, St Mary's Hospital Medical School, University of London.

The title of professor of computing science has been conferred on Mr I. M. Khabaza in respect of his post at Queen Mary College, University of London.

The title of professor of human metabolism has been conferred on Dr V. Wynn, St Mary's Hospital Medical School, University of London.

Dr Alan Lees, University of Reading, has been appointed to a chair in the Institut Géologique of the University of Louvain, Belgium.

Dr B. E. Johnson has been appointed to a professorship of pure mathematics in the School of Mathematics, University of Newcastle upon Tyne.

\section{Appointments}

Dr R. J. Ward, Reckitts and Sons, has joined the staff of Canterbury Biological Laboratories, Ash, Kent, as research director.

Dr L. M. Branscomb has been nominated as director of the National Bureau of Standards, in suecession to Dr A. V. Astin, who is retiring.

\section{Announcements}

The second Philips European Young Scientists and Inventors Contest will be held at Eindhoven, Holland, next year. Projects eligible for the competition cover the wide fields of the physical and natural sciences as well as engineering and mathematics. Two teams will again be invited to represent Great Britain. They will be chosen from the already existing "Science Fairs", organized by the British Association for the Advancement of Science and the Sunday Times. This year, fairs will be held in Portsmouth, Oxford and Liverpool during July, and Exeter, Leicester and Birmingham during September. Further information can be obtained from Brian Hetherington, Chief Press Officer, Philips Electrical Limited, Telephone No. 01-437 7777 Ext. 88.

The medal for Distinguished Public Service of the US Department of Defense has been awarded to Dr R. E. Gibson, who has just retired as director of the applied physics laboratory at the Johns Hopkins University, in recognition of his work in missile technology for fleet defence.

Dr J. J. Fennessy, Pritzker School of Medicine of the University of Chicago, has received the university's J. A. McClintock Award, given annually for outstanding teaching.

Erratum. In the article "Racial Differences in the Fate of Melanosomes in Human Epidermis" by Szabó et al. (Nature, 222, 1081; 1969) the second sentence of the thircl paragraph on page 1082 should read "After irradiation, the number of melanosomes increases in the keratocytes of all races".

Erratum. In the letter "Simplified Notation for Peptides in Computer Compatible Format" from Gabrielle S. Revesz (Nature, 222, 1209; 1969), a list of possible additions to the one-letter notation for amino-acids was printed without the distinguishing symbol "@)". A-G are, of course, already part of the IUPAC-IUB tentativo rules; in their place read $\mathbf{A} @, \mathbf{B}(a), \mathrm{C}(\mathfrak{a}, \mathrm{D}(\underline{a}, \mathrm{E} a$. $\mathrm{F}(\mathrm{r}), \mathrm{G}(\mathrm{c})$ 